\title{
PENGIMBASAN KETAHANAN BIBIT PISANG AMBON KUNING TERHADAP PENYAKIT LAYU FUSARIUM DENGAN BEBERAPA JAMUR ANTAGONIS
}

\author{
Loekas Soesanto $^{1}$ dan Ruth Feti Rahayuniati ${ }^{1}$
}

\begin{abstract}
Induced resistance of Ambon Kuning cultivar banana seedling to fusarium wilt with antagonistic fungi. A research aiming at knowing the effect of antagonistic fungi supernatant on banana induced resistance, Fusarium wilt development, and banana growth was carried out from July up to December 2008. Randomized Block Design was used with four replicates. Treatments tested were control, with supernatant of Gliocladium virens, Trichoderma harzianum isolated from banana, ginger, and ginseng, Trichoderma koningii, and Fusarium equiseti, applied by injection to banana seedling corm and soaked for five minutes. Variables observed were incubation period, disease severity, Foc population density, germination inhibition, growth component, phenolic compound content, and supporting component. Result of the research indicated that the supernatant of $G$. virens, T. harzianum, and T. koningii could significantly induce resistance of the seedling showed by increasing the phenolic content such as glycoside, saponin, and tannin. The supernatant of all antagonistic fungi could effectively control the disease showed by lengthening incubation period as $48.71 \%$, decreasing the disease severity as $53.57 \%$, decreasing infection rate as $61.48 \%$, increasing the antagonistic effectivity as $51.26 \%$, decreasing the late population density as $45.35 \%$, and decreasing the inoculum inside the plant as 60-100\%. The extract could improve the seedling growth.
\end{abstract}

Key words: Induced resistance, supernatant, antagonistic fungi, Ambon Kuning cultivar banana seedling

\section{PENDAHULUAN}

Buah pisang banyak digemari orang, karena rasanya yang enak, dan dapat dijadikan sebagai komoditas andalan Indonesia dalam meningkatkan ekspor "non-migas". Namun kenyataannya, tingginya produksi pisang belum dapat menjadi bagian dari sumber pendapatan negara. Hal ini ditunjukan pada tahun 2005, volume ekspor pisang mencapai angka 5,177 juta ton dan setelah itu mengalami penurunan sampai 0,14 juta ton pada tahun 2006 (BPS, 2008).

Upaya peningkatan produksi pisang dalam memenuhi kebutuhan dalam dan luar negeri selalu berhadapan dengan kendala lingkungan. Salah satu kendala lingkungan yang harus dihadapi dalam usaha meningkatkan produksi pisang di Indonesia adalah gangguan organisme pengganggu tanaman (OPT). Salah satu OPT penting pada tanaman pisang adalah jamur Fusarium oxysporum f.sp. cubense (Foc). Jamur ini menyebabkan kelayuan pada tanaman dan dikenal dengan penyakit layu fusarium atau penyakit Panama. Penyakit layu fusarium merupakan penyakit penting pada pisang di seluruh dunia, termasuk Indonesia, terutama di Jawa, Sumatera dan Sulawesi (Buddenhagen, 1995 cit. Nasir et al., 1999), bahkan termasuk kelompok yang sangat merugikan (Semangun, 2000). Hingga tahun 1997, lebih kurang 5000 ha perkebunan komersial pisang Cavendish di Indonesia hancur karena Foc (Daryanto, 2002; Nasir et al., 2003; Suyadi, 2004). Foc telah menyerang tanaman pisang di beberapa kabupaten di Kalimantan Timur. Areal yang terserang mencapai 11.000 hektar dari luas total lahan budidaya pisang 30.000 hektar (Kompas, 2007).

Strategi pengendalian penyakit Panama yang telah terbukti berhasil adalah penerapan karantina lokal dan mengganti jenis rentan dengan jenis tahan (Pegg et al., 1996). Keberhasilan program tersebut dapat terjadi bila pisang merupakan buah eksotik, jenis tahan tersedia, bahan tanaman dapat dikendalikan, keragaman patogen terbatas, dan sebaran strain patogen diketahui. Hal ini belum sepenuhnya dilaksanakan di Indonesia.

Antagonis, baik jamur maupun bakteri, akhir-akhir ini banyak digunakan kaitannya dengan upaya penemuan cara pengendalian penyakit tanaman yang ramah

${ }^{1}$ Jurusan Hama dan Penyakit Tumbuhan, Fakultas Pertanian, Universitas Jenderal Soedirman,

J1. Dr. Soeparno Karang Wangkal Purwokerto 53123 Purwokerto. Emai1 : lukassus26@gmail. com 
lingkungan. Penggunaan antagonis ini muncul akibat dampak negatif yang ditimbulkan oleh fungisida, baik terhadap lingkungan, manusia, maupun produk tanaman (Untung, 1996; Gamliel et al., 1997).

Pengendalian hayati penyakit yang disebabkan oleh fusarium dapat dilakukan dengan menambahkan antagonis dan bahan organik ke dalam tanah (Rustati et al., 2004). Perlakuan dengan Trichoderma harzianum dapat menghambat masa inkubasi $F$. oxysporum f. sp. zingiberi pada jahe (Soesanto et al., 2005). Ketahanan tanaman terhadap patogen ditunjukkan dengan ketahanannya terhadap infeksi patogen, atau tanaman dapat terinfeksi patogen, namun dapat membatasi aktivitas patogen, sehingga patogen tidak dapat berkembang dan tidak dapat menyebabkan kerusakan berat (Agrios, 2005). Ketahanan kimiawi ditunjukkan dengan terbentuknya senyawa kimia yang mampu mencegah pertumbuhan dan perkembangan patogen, yang dapat berupa PR protein (Pathogenesis-Related Proteins), metabolit sekunder berupa senyawa alkaloida, fenol, flavonida, glikosida, fitoaleksin, dan sebagainya (Chairul, 2000 cit. Chairul, 2003). Umumnya, tanaman tahan mengandung senyawa kimia tersebut dengan konsentrasi lebih tinggi daripada tanaman tidak tahan (Mansfield, 2000; Agrios, 2005). Penggunaan jamur antagonis merupakan salah satu strategi yang dapat diterapkan untuk meningkatkan ketahanan tanaman, melalui mekanisme pengimbasan ketahanan. Jamur antagonis yang paling efektif dalam pengimbasan ketahanan tanaman pisang terhadap penyakit layu fusarium sampai saat ini belum banyak diteliti.

Penelitian ini bertujuan untuk mengetahui: 1) pengaruh supernatan jamur antagonis terhadap peningkatan ketahanan bibit pisang Ambon Kuning terhadap penyakit layu fusarium, 2) pengaruh supernatan jamur antagonis terhadap penyakit layu fusarium pada bibit pisang Ambon Kuning, dan 3) pengaruh supernatan jamur antagonis terhadap pertumbuhan bibit tanaman pisang Ambon Kuning.

\section{METODE PENELITIAN}

Penelitian dilaksanakan selama enam bulan sejak bulan Juli sampai Desember 2008, dilakukan di Laboratorium Ilmu Penyakit Tumbuhan dan Kebun Percobaan Fakultas Pertanian, Universitas Jenderal Soedirman.
Perbanyakan isolat. Biakan murni Foc (koleksi L. Soesanto) diperbanyak pada medium ke dalam Potato Dextrose Liquid (PDL) secara aseptis dalam labu Erlenmeyer, kemudian digoyang dengan kecepatan 150 rpm selama 4 hari pada suhu kamar. Antagonis ( $T$. harzianum, T. koningii, G. virens, dan F. equiseti) diperbanyak dalam medium PDL, digojog selama lima hari dengan kecepatan $150 \mathrm{rpm}$ pada suhu ruang $28^{\circ} \mathrm{C}$. Setiap antagonis dihitung kerapatannya sebesar $4 \times 10^{7}$ konidium $\mathrm{ml}^{-1}$. Selanjutnya, antagonis disentrifus pada kecepatan 1200 rpm selama 20 menit untuk memisahkan pelet dan supernatan. Supernatan yang dihasilkan kemudian digunakan dalam penelitian.

Persiapan bahan tanaman. Bahan tanaman yang digunakan adalah bibit pisang Ambon Kuning hasil kultur jaringan umur 2 minggu setelah aklimatisasi I dari Balai Benih Induk (BBI) Hortikultura Salaman, Magelang.

Penyiapan medium tanam. Medium tanam yang digunakan adalah pasir sungai steril, yang sebelumnya dicuci sampai bersih untuk menghilangkan kotoran dan lumpur. Selanjutnya, pasir dimasukkan ke dalam kantong dan disterilkan dengan uap panas selama 2 sampai 3 jam. Setelah itu, pasir didinginkan dan dimasukkan ke dalam polybag ukuran $0,5 \mathrm{~kg}$ sebanyak $3 / 4$ bagian dari polybag tersebut.

Pelaksanaan penelitian. Bibit pisang diambil dari medium awalnya, dibersihkan dari tanah yang menempel, dan siap digunakan. Pada percobaan ini, rancangan yang digunakan adalah Rancangan Acak Kelompok dengan 4 ulangan. Perlakuan yang dicoba adalah K0 = Bibit pisang tanpa perlakuan (Kontrol), THP = Bibit disuntik dengan $5 \mathrm{ml}$ supernatan T. harzianum isolat pisang dan direndam dalam supernatan selama 5 menit, $\mathrm{THG}=$ Bibit disuntik $5 \mathrm{ml}$ supernatan $T$. harzianum isolat ginseng dan direndam dalam supernatan selama 5 menit, $\mathrm{THJ}=$ Bibit disuntik $5 \mathrm{ml}$ supernatan T. harzianum isolat jahe dan direndam dalam supernatan selama 5 menit, TK = Bibit disuntik $5 \mathrm{ml}$ supernatan $T$. koningii isolat pisang dan direndam dalam supernatan selama 5 menit, $\mathrm{GV}=$ Bibit disuntik $5 \mathrm{ml}$ supernatan $G$. virens dan direndam dalam supernatan selama 5 menit, dan $\mathrm{FE}=$ Bibit disuntik $5 \mathrm{ml}$ supernatan $F$. equiseti dan direndam dalam supernatan selama 5 menit. 
Selanjutnya, bibit ditanam dalam polybag berisi pasir sungai steril. Bibit dipelihara di rumah kasa. Setelah 1 minggu, dilakukan inokulasi dengan cara menyiramkan suspensi Foc, dengan kepadatan $2 \times 10^{7}$ konidium ml $^{-1}$, ke daerah perakaran tanaman yang telah dilukai sebanyak $20 \mathrm{ml} /$ tanaman. Pemeliharaan tanaman dilakukan antara lain dengan pemberian nutrisi larutan Hoagland (Lo, 2002) sebanyak $10 \mathrm{ml}$ tanaman $^{-1}$ setiap 2 hari sekali, dan penyiraman.

Pengamatan. Pengamatan dilakukan terhadap masa inkubasi, yang dihitung sejak dilakukannya inokulasi sampai gejala awal nampak, dengan satuan hari setelah inokulasi (hsi). Selanjutnya dilakukan penghitungan keparahan penyakit dengan menggunakan kategori serangan atau skala kerusakan mengacu pada skala kerusakan menurut Mak et al. (2008), yaitu untuk gejala pada daun, skala kerusakannya adalah $1=$ tidak ada infeksi (tanaman sehat), $2=$ daun sedikit menguning, 3 = sebagian besar daun menguning, $4=$ semua daun menguning, dan $5=$ tanaman mati; untuk gejala pada akar, skala kerusakannya adalah $1=$ Jaringan pada bagian atau sekitar bonggol tidak ada perubahan warna, $2=$ tidak ada perubahan warna pada bagian bonggol, perubahan warna terdapat pada bagian yang berhubungan dengan akar, $3=$ perubahan warna 0 $5 \%, 4=$ perubahan warna $6-20 \%, 5=$ perubahan warna $21-50 \%, 6=$ perubahan warna $>50 \%, 7=$ perubahan warna mencapai bonggol tanaman, dan $8=$ tanaman mati. Menurut Mak et al. (2008), keparahan penyakit (disease severity index/DSI) pada daun dan akar dihitung dengan rumus:

DSI $=\frac{\sum \text { (Nilai kategori x jumlah bibit tiap kategori serangan) }}{\sum \text { (Jumlah bibit yang diamati) }}$
Laju infeksi dihitung berdasarkan rumus van der Plank (1963): $r=2,3 / t(\log 1 /(1-X t)-\log 1 /(1-X o))$, dengan $\mathrm{R}$ = laju infeksi, $\mathrm{Xo}=$ proporsi penyakit awal, $\mathrm{Xt}$ $=$ proporsi penyakit pada waktu $\mathrm{t}$, dan $\mathrm{T}=$ waktu pengamatan. Keefektifan jamur antagonis dihitung berdasarkan rumus (Djaya et al., 2003): $\mathrm{Ea}=(\mathrm{IPk}-$ $\mathrm{IPp}) / \mathrm{IPk} \times 100 \%$, dengan $\mathrm{Ea}=$ keefektifan antagonis, $\mathrm{IPk}=$ Intensitas penyakit pada kontrol/tanpa perlakuan, dan IPp = Intensitas penyakit pada perlakukan.

Kepadatan populasi Fusarium total dihitung di akhir penelitian (91 hari), dengan menghitung langsung sampel tanah sebanyak $1 \mathrm{~g}$ yang dilarutkan dalam $9 \mathrm{ml}$ air steril, dan dihitung dengan haemositometer. Pengamatan terhadap kandungan senyawa fenol dilakukan terhadap glikosida, saponin, dan tanin berdasar Chairul (2003) yang dimodifikasi dan dilakukan di akhir penelitian. Uji glikosida dilakukan dengan pereaksi Keller-Kiliani. Uji tannin diidentifikasi dengan uji gelatin dan pereaksi $\mathrm{FeCl}_{3}$. Uji saponin dilakukan menggunakan uji busa/buih (the froth test).

Pengamatan perkembangan jamur di dalam tanaman dilakukan dengan mengisolasi Foc dari akar dan bonggol tanaman. Akar dan bonggol dipotong, direndam dalam larutan kloroks $1 \%$ selama 5 menit, dicuci dua kali dengan akuades, dan dikeringkan di atas kertas saring steril. Setelah kering, bahan dipotong sepanjang $1 \mathrm{~cm}$ dan diisolasi pada medium PDA dalam cawan petri. Setiap cawan petri diisi 10 potongan akar atau bonggol dan diinkubasi minimum 3 hari. Isolat yang tumbuh diamati dengan mikroskop dengan pewarnaan lactophenol cotton blue. Selain itu, dilakukan

Tabel 1. Keterangan Skala DSI

\begin{tabular}{ccc}
\hline Skala DSI untuk LSI & Skala DSI untuk RDI & Keterangan \\
\hline 1 & 1 & Tahan \\
$1,1-2$ & $1,1-3$ & Toleran \\
$2,1-3$ & $3,1-5$ & Rentan \\
$3,1-4$ & $5,1-8$ & Sangat rentan \\
\hline
\end{tabular}


pengamatan dengan membuat irisan melintang akar, yang diwarnai dengan lactophenol cotton blue.

Uji penghambatan perkecambahan konidium dilakukan untuk mengetahui persentase penghambatan metabolit sekunder yang dihasilkan oleh jamur antagonis terhadap perkecambahan konidium patogen. Pengujian dilakukan menurut Wirianata (2004) yang dimodifikasi, yaitu gelas benda dicelupkan ke dalam gom Arab 1\%, kemudian dikeringanginkan. Satu g akar atau bonggol yang sudah dibersihkan dihaluskan dalam mortar porselin dan ditambahkan $5 \mathrm{ml}$ air steril. Sebanyak $20 \mu \mathrm{l} \mathrm{ekstrak}$ akar atau bonggol diteteskan pada gelas benda tersebut, diratakan, dan dikeringanginkan. Selanjutnya ditetesi dengan suspensi konidium sebanyak $10 \mu \mathrm{l}$. Gelas benda tersebut diinkubasi pada cawan petri yang telah dialasi kertas saring lembab. Pertumbuhan buluh kecambah dihentikan dengan meneteskan larutan lactophenol cotton blue 3 jam setelah perlakuan. Selanjutnya dilakukan pengamatan dengan mikroskop. Persentase perkecambahan dihitung dengan membandingkan jumlah konidium yang berkecambah dengan jumlah konidium totalnya.

Pengamatan terhadap pertumbuhan bibit pisang dilakukan dengan mengukur tinggi tanaman awal dan akhir, panjang akar terpanjang, dan diameter batang semu; sedangkan penimbangan dilakukan terhadap akar segar dan penghitungan jumlah akar dan daun. Semua parameter tersebut, selain tinggi tanaman awal, diukur di akhir penelitian untuk setiap bibit pisang.

Analisis Data. Data yang diperoleh dianalisis dengan menggunakan uji F. Apabila terdapat perbedaan nyata, dilanjutkan dengan DMRT pada taraf 5\%.

\section{HASIL DAN PEMBAHASAN}

Analisis Jaringan. Hasil analisis kandungan senyawa fenol, pengaruh supernatan terhadap perkecambahan konidium, dan keberadaan Foc dapat dilihat pada Tabel 2.

Analisis Kandungan Senyawa Fenol. Berdasarkan hasil pengujian secara kualitatif diketahui bahwa kandungan glikosida, tannin, dan saponin pada tanaman mengalami peningkatan secara kualitatif setelah diperlakukan dengan supernatan jamur antagonis. Kandungan glikosida tertinggi terdapat pada tanaman yang diperlakukan dengan $T$. harzianum isolat pisang. Kandungan tanin tanaman yang diperlakukan dengan
T. harzianum baik isolat pisang, isolat jahe, isolat ginseng, maupun T. koningii, lebih tinggi daripada perlakuan dengan jamur antagonis lain. Sementara itu, kandungan saponin tertinggi ter jadi pada tanaman yang diperlakukan dengan $T$. harzianum isolat pisang dan isolat jahe.

Oleh karena itu, secara umum dapat dikatakan bahwa penyuntikan dan perendaman supernatan jamur antagonis, khususnya Trichoderma, mampu meningkatkan ketahanan biokimia tanaman pisang terhadap penyakit layu fusarium. Hal ini sesuai dengan pendapat De Meyer et al. (1998) dan Levy et al. (2004), yang mengatakan bahwa salah satu mekanisme penghambatan terhadap Botrytis cinerea oleh Trichoderma harzianum T39 adalah pengimbasan ketahanan lokal maupun sistemik pada tanaman inangnya. Ketahanan tanaman terhadap penyakit merupakan suatu sifat yang memungkinkan tanaman terhindar, mempunyai daya tahan terhadap serangan patogen dalam kondisi yang sesuai. Ketahanan secara biokimia ditunjukkan dengan menghasilkan senyawa yang bersifat toksin atau menghambat pertumbuhan patogen (Hammerschmidt \& Dann, 2000). Mekanisme ini tidak menghambat pertumbuhan tanaman, bahkan dapat meningkatkan produksi dan ketahanan terhadap stres lingkungan pada beberapa tanaman (Hammerschmidt \& Dann, 2000; Vallad \& Goodman, 2004; Desmawati, 2006).

Sistem pertahanan tanaman sangat bergantung kepada interaksi inang, patogen, dan lingkungan. Interaksi antara tanaman dengan patogen akan menghasilkan reaksi kesesuaian (infeksi) atau ketidaksesuaian (ketahanan) (Hammerschmidt \& Dann, 2000; Heil \& Bostock, 2002). Menurut Suganda (2000), reaksi ketahanan dapat muncul dari hasil ekspresi adanya ketahanan terimbas, yang merupakan hasil ekspresi dari serangkaian gen pertahanan yang teraktifkan oleh rangsangan dari luar. Tanggapan sistemik terjadi saat pengimbasan senyawa PR protein dan asam salisilat dapat ditransfer antarsel ke seluruh bagian tanaman (Hammerschmidt \& Dann, 2000; Heil \& Bostock, 2002; Vallad \& Goodman, 2004).

Peningkatan kandungan fenol dalam tanaman karena terimbas oleh penambahan metabolit jamur antagonis ke dalam jaringan tanaman, dapat diketahui dari kadar glikosida, tannin, dan saponinnya yang terlihat menunjukkan peningkatan kualitas kandungan fenol pada tanaman (Tabel 2). Peningkatan kandungan fenol akibat penambahan metabolit jamur antagonis diduga karena 
supernatan jamur antagonis yang digunakan untuk menyelup bibit pisang, diserap oleh bibit pisang dan ditranslokasikan secara sistemik ke seluruh bagian bibit pisang, menimbulkan zat yang bertanggung jawab dalam ketahanan terimbas, di antaranya adalah senyawa fenol (Agrios, 2005).

Penghambatan perkecambahan konidium jamur. Dari hasil pengamatan penghambatan perkecambahan konidium jamur dengan menggunakan supernatan jaringan tanaman, diketahui bahwa jaringan tanaman yang diberi perlakuan supernatan jamur antagonis memberikan pengaruh penghambatan yang cukup baik daripada kontrol (Tabel 2). Penghambatan perkecambahan konidium ini diduga karena adanya peningkatan senyawa fenol pada jaringan tanaman yang dapat menghambat perkecambahan konidium $F$. oxysporum. Senyawa fenol dalam tanaman merupakan senyawa yang digunakan sebagai pertahanan tanaman terhadap patogen (Naim, 2004; Anonim, 2008).

Keberadaan Foc pada akar dan bonggal. Aplikasi supernatan antagonis menurunkan keberadaan Foc pada akar dan bonggol pisang (Tabel 2). Keberadaan Foc

Tabel 2. Analisis jaringan bibit pisang

\begin{tabular}{|c|c|c|c|c|c|c|}
\hline \multirow{2}{*}{ Perlakuan } & \multicolumn{3}{|c|}{ Pengujian kandungan fenol (Kualitatif) } & \multirow{2}{*}{$\begin{array}{l}\text { Perkecambahan } \\
\text { Konidium Foc }\end{array}$} & \multicolumn{2}{|c|}{ Keberadaan Foc $(\%)$} \\
\hline & Glikosida & Tanin & Saponin & & akar & Bonggol \\
\hline $\mathrm{KO}$ & + & + & ++++ & $\overline{++++}$ & $70,0 \mathrm{bc}$ & $100,0 \mathrm{~b}$ \\
\hline FE & ++ & ++ & +++ & +++ & $90,0 \mathrm{c}$ & $100,0 \mathrm{~b}$ \\
\hline TK & ++ & +++ & + & + & $40,0 \mathrm{ab}$ & $20,0 \mathrm{a}$ \\
\hline GV & + & + & ++ & ++ & $20,0 \mathrm{a}$ & $20,0 \mathrm{a}$ \\
\hline THP & +++ & +++ & + & + & $10,0 \mathrm{a}$ & $0,0 \mathrm{a}$ \\
\hline THG & ++ & +++ & ++ & ++ & $50,0 \mathrm{abc}$ & $40,0 \mathrm{a}$ \\
\hline THJ & ++ & +++ & + & + & $10,0 \mathrm{a}$ & $10,0 \mathrm{a}$ \\
\hline
\end{tabular}

Keterangan: $\mathrm{KO}=$ Kontrol, $\mathrm{FE}=$ Supernatan $F$. equseti, $\mathrm{TK}=$ Supernatan $T$. koningii, $\mathrm{GV}=$ Supernatan $G$. virens, $\mathrm{THP}=$ Supernatan $T$. harzianum isolat pisang, $\mathrm{THG}=$ Supernatan $T$. harzianum isolat gingseng, dan $\mathrm{THJ}=$ Supernatan $T$. harzianum isolat jahe. Keterangan: - = tidak ada kandungan fenol, $+=$ sedikit, $++=$ cukup,$+++=$ banyak. Pada perkecambahan: $-=$ tidak ada perkecambahan,$+=$ sedikit,$++=$ cukup,$+++=$ banyak,$++++=$ sangat banyak. Angka yang diikuti huruf yang sama pada kolom yang sama tidak berbeda nyata menurut DMRT taraf 5\%.

Tabel 3. Pengaruh Perlakuan terhadap komponen patosistem

\begin{tabular}{|c|c|c|c|c|c|c|c|c|c|}
\hline \multirow[b]{2}{*}{ Perlakuan } & \multirow{2}{*}{$\begin{array}{c}\text { Masa } \\
\text { inkubasi } \\
(\mathrm{hsi})\end{array}$} & \multicolumn{4}{|c|}{ Keparahan Penyakit } & \multirow{2}{*}{$\begin{array}{l}\text { Laju infeksi } \\
\text { (unit/hari) }^{\text {tn }}\end{array}$} & \multirow{2}{*}{$\begin{array}{l}\text { Populasi } \\
\text { Fusarium } \\
\text { akhir }\end{array}$} & \multicolumn{2}{|c|}{$\begin{array}{c}\text { Keefektifan } \\
\text { antagonis }(\%)\end{array}$} \\
\hline & & $\begin{array}{l}\text { Pada } \\
\text { daun }\end{array}$ & $\begin{array}{c}\text { Tingkat } \\
\text { ketahanan }\end{array}$ & $\begin{array}{c}\text { Pada } \\
\text { bonggol }\end{array}$ & $\begin{array}{c}\text { Tingkat } \\
\text { ketahanan }\end{array}$ & & & $\begin{array}{l}\text { Pada } \\
\text { daun }\end{array}$ & $\begin{array}{c}\text { Pada } \\
\text { bonggol }\end{array}$ \\
\hline $\mathrm{KO}$ & $44 \mathrm{~b}$ & $1,80 \mathrm{~b}$ & Toleran & $4,48 \mathrm{c}$ & Rentan & $0,00270 \mathrm{~b}$ & $9,60 \times 10^{2}$ & $0 \mathrm{a}$ & $0 \mathrm{a}$ \\
\hline $\mathrm{FE}$ & $64 \mathrm{a}$ & $1,52 \mathrm{ab}$ & Toleran & $3,23 \mathrm{~b}$ & Rentan & $0,00215 \mathrm{ab}$ & $11,9 \times 10^{2}$ & $42,800 \mathrm{ab}$ & $38,408 \mathrm{ab}$ \\
\hline TK & $69 \mathrm{a}$ & $1,36 \mathrm{a}$ & Toleran & $2,32 \mathrm{ab}$ & Toleran & $0,00115 \mathrm{a}$ & $7,75 \times 10^{2}$ & $52,930 \mathrm{~b}$ & $46,890 \mathrm{~b}$ \\
\hline GV & $68 \mathrm{a}$ & $1,36 \mathrm{a}$ & Toleran & $2,66 \mathrm{ab}$ & Toleran & $0,00105 \mathrm{a}$ & $6,41 \times 10^{2}$ & $50,695 \mathrm{~b}$ & $46,888 \mathrm{~b}$ \\
\hline THP & $69 a$ & $1,29 \mathrm{a}$ & Toleran & $2,08 \mathrm{a}$ & Toleran & $0,00103 \mathrm{a}$ & $5,25 \times 10^{2}$ & $58,563 \mathrm{~b}$ & $49,465 \mathrm{~b}$ \\
\hline THG & $60 \mathrm{a}$ & $1,39 \mathrm{a}$ & Toleran & $2,31 \mathrm{ab}$ & Toleran & $0,00130 \mathrm{a}$ & $7,25 \times 10^{2}$ & $58,533 \mathrm{~b}$ & $45,573 \mathrm{~b}$ \\
\hline THJ & $68 \mathrm{a}$ & $1,33 \mathrm{a}$ & Toleran & $2,08 \mathrm{a}$ & Toleran & $0,00100 \mathrm{a}$ & $7,08 \times 10^{2}$ & $55,205 \mathrm{~b}$ & $47,965 \mathrm{~b}$ \\
\hline
\end{tabular}

Keterangan: $\mathrm{KO}=$ Kontrol, $\mathrm{FE}=$ Supernatan $F$. equseti, $\mathrm{TK}=$ Supernatan $T$. koningii, $\mathrm{GV}=$ Supernatan G. virens, THP $=$ Supernatan $T$. harzianum isolat pisang, $\mathrm{THG}=$ Supernatan $T$. harzianum isolat gingseng, dan $\mathrm{THJ}=$ Supernatan $T$. harzianum isolat jahe. Angka yang diikuti huruf yang sama pada kolom yang sama tidak berbeda nyata menurut DMRT taraf $5 \%$. 
pada akar terendah pada perlakuan THJ dan THP, masing-masing sebesar $10 \%$ atau terjadi penurunan sebesar $60 \%$. Keberadaan Foc pada bonggol tertinggi pada KO dan FE, sebesar $100 \%$, sedang terendah pada perlakuan THP, sebesar $0 \%$ atau terjadi penurunan $100 \%$. Keberadaan Foc pada bonggol ini erat kaitannya dengan peningkatan produksi senyawa fenol pada bibit pisang (Tabel 2). Aplikasi supernatan jamur antagonis mampu mengimbas ketahanan bibit pisang terhadap jamur $F$. oxysporum. Pengimbasan ini terbukti dengan peningkatan senyawa fenol pada tanaman pisang yang diperlakukan dengan supernatan jamur antagonis. Hal ini sesuai dengan penelitian Adriansyah (2002), yang menyatakan bahwa metabolit sekunder jamur $T$. harzianum dapat mengendalikan pertumbuhan dan perkembangan $F$. oxysporum.

Masa inkubasi. Perlakuan aplikasi supernatan jamur antagonis berpengaruh nyata terhadap masa inkubasi (Tabel 3). Kontrol (KO) memiliki masa inkubasi tercepat, yaitu 44,9 hsi. Hal itu diduga karena tanaman tidak mempunyai mekanisme penekanan terhadap infeksi Foc. Penekanan tersebut dapat terjadi dengan pemberian mikroba antagonis, bahan kimia, kompos, ekstrak tanaman bukan inang, dan medium tanaman (Hammerschmidt \& Dann, 2000; Suganda, 2000). Penelitian yang dilakukan oleh Kuswinanti (2006) menunjukkan bahwa pemberian T. harzianum dan G. virens dapat menekan pertumbuhan Sclerotium rolfsii pada tanaman kacang tanah. Syatrawati (2005) melaporkan bahwa aplikasi supernatan Gliocladium sp. ke dalam tanah di rumah kaca tujuh hari sebelum penanaman kedelai dapat menekan serangan Pythium aphanidermatum sebesar $90 \%$, Rhizoctonia solani sebesar $88,4 \%$ dan Sclerotium rolfsii sebesar $85 \%$. Selanjutnya diberitahukan bahwa filtrat $G$. virens mampu menghambat pertumbuhan radikal hifa Ralstonia solani dengan konsentrasi awal $10^{6}$ konidium $/ \mathrm{ml}$.

Keadaan ini berbeda dengan masa inkubasi pada perlakuan dengan pemberian supernatan jamur antagonis. Perlakuan supernatan jamur antagonis satu dengan yang lainnya tidak berbeda nyata. Akan tetapi, semua perlakuan ini berbeda nyata dengan kontrol (KO) atau terjadi penghambatan $48,71 \%$. Hal ini diduga dengan aplikasi supernatan jamur antagonis ini mampu mengimbas ketahanan pada tanaman pisang (Tabel 2).

Menurut Cutler et al. (1999), metabolit T. koningii bersifat antimikroba, immunosuppressants, perangsang tumbuh, dan mikotoksin. Berdasarkan hal tersebut, maka dapat diduga bahwa terhambatnya perkembangan layu terjadi karena metabolit yang dihasilkan Trichoderma maupun Gliocladium, yang mampu menghambat perkembangan jamur Foc di dalam jaringan pembuluh tanaman. Soesanto et al. (2008) menyatakan bahwa masa inkubasi jamur patogen F. oxysporum f.sp. gladioli, yang diperlakukan dengan T. harzianum dan Gliocladium sp., lebih lama bila dibandingkan dengan kontrol.

Keparahan Penyakit. Keparahan penyakit layu fusarium pada tanaman pisang, yang diukur pada daun dan akar tanaman pisang, disajikan dalam Tabel 3. Hal ini dilakukan karena diduga keberadaan Foc di bonggol belum tentu memunculkan gejala penyakit pada daun, ataupun sebaliknya, daun yang terlihat sehat belum tentu di akar atau bonggolnya terbebas dari Fusarium.

Hasil pengamatan menunjukkan, kategori keparahan penyakit pada daun tertinggi adalah $\mathrm{KO}$, yaitu sebesar 1,8 yang berbeda nyata dengan perlakuan lainnya. Keparahan penyakit antar perlakuan supernatan jamur antagonis satu dengan yang lain tidak berbeda nyata. Hal ini diduga dengan adanya penyuntikan terhadap bibit pisang mampu mengimbas ketahanan pada bibit pisang, sehingga dapat memperendah keparahan penyakit. Hal ini sesuai dengan hasil pengamatan terhadap kandungan senyawa fenol pada tanaman pisang (Tabel 2). Selain itu, intensitas penyakit dipengaruhi oleh kevirulenan patogen, kondisi lingkungan, dan tanaman inang rentan. Tanaman muda lebih rentan terhadap patogen dan patogen yang virulen dengan kondisi lingkungan yang sesuai untuk perkembangan patogen menyebabkan kemungkinan terjadinya penyakit semakin besar (Agrios, 2005).

Pada bonggol, kategori keparahan penyakit menunjukan perbedaan antara $\mathrm{KO}$ dengan perlakuan lain. Perlakuan yang kategori keparahan penyakitnya tertinggi adalah KO yaitu sebesar 4,485 , sedangkan kategori keparahan penyakit terendah adalah perlakuan THP dan THJ, yaitu masing-masing sebesar 2,085 atau terjadi penurunan $53,57 \%$. Tingkat keparahan penyakit cukup tinggi terdapat pada kontrol, bila dibandingkan dengan perlakuan supernatan jamur antagonis. Aplikasi supernatan jamur antagonis, baik Trichoderma, Gliocladium maupun $F$. equiseti, terbukti efektif menurunkan keparahan penyakit. Hal ini sesuai dengan data masa inkubasi (Tabel 3).

Aplikasi supernatan antagonis melalui perendaman dan penyuntikan bibit tampak sangat berpengaruh terhadap keparahan penyakit pada bonggol dan daun. Hal ini sejalan dengan pendapat Agrios (2005), 
yang menyatakan bahwa selain sebagai hasil infeksi primer, ketahanan terimbas juga dapat ditimbulkan dengan memperlakukan tumbuhan dengan senyawa alam, seperti protein dinding virus, protein, lipoprotein, polisakarida jamur atau bakteri, RNA ragi, dan dengan molekul sintesis. Senyawa tersebut bertindak sebagai pengimbas ketahanan lokal pada tumbuhan apabila digunakan dengan disuntikkan atau disemprotkan. Ketahanan sistemik timbul apabila senyawa tersebut diserap melalui tangkai daun atau akar.

Penghambatan tersebut menyebabkan Foc tidak dapat menyebar ke seluruh jaringan tanaman atau dengan kata lain lokasi serangan terbatas, sehingga keparahan penyakit tidak tinggi (Eziashi et al., 2006). Hasil ini juga sesuai dengan hasil penelitian Santoso et al. (2007) dan Soesanto et al. (2008), yang menggambarkan penekanan Fusarium, masing-masing pada tanaman bawang merah dan gladiol, dengan aplikasi antagonis T. harzianum dan T. koningii.

Selain mekanisme ketahanan terimbas, diduga penghambatan pertumbuhan Foc tersebut disebabkan oleh mekanisme lain pada bibit pisang, seperti pembentukan struktur pertahanan sebagai tanggapan terhadap infeksi patogen serta pembentukan struktur pertahanan sel dan reaksi pertahanan sitoplasma. Pertahanan biokimia dalam tanaman juga mendukung berlangsungnya penghambatan terhadap patogen. Pembentukan pertahanan biokimia tersebut antara lain melalui hipersensitif dan peningkatan kadar senyawa fenol (Agrios, 2005).

Penggunaan supernatan $F$. equiseti tidak berpengaruh nyata terhadap ketahanan bibit pisang, yaitu menunjukkan kerentanan terhadap penyakit layu fusarium berdasarkan keparahan penyakit pada daun (Tabel 3). Hal ini sama dengan KO, akan tetapi penggunaan supernatan $F$. equiseti berbeda nyata dengan kontrol pada keparahan penyakit pada bonggol. Hal ini sesuai dengan aplikasi jamur $F$. equiseti secara langsung sebagai antagonis penyakit busuk hati pada pisang Cavendish yang dapat menurunkan intensitas penyakit sampai 14,23\% (Haryono, 2007). Namun, secara umum dapat dikatakan bahwa aplikasi supernatan jamur antagonis mampu sebagai pengimbas ketahanan bibit pisang Ambon Kuning dan mampu menekan keparahan penyakit layu Fusarium.

Laju Infeksi. Pengamatan laju infeksi dimulai pada saat awal sampai berakhirnya pengamatan intensitas penyakit, yaitu pada saat pemanenan, sehingga diperoleh interval waktu 91 hari. Perlakuan penyuntikan supernatan jamur antagonis berpengaruh nyata terhadap laju infeksi. Laju infeksi paling tinggi ditunjukkan pada perlakuan KO, yaitu sebesar 0,00270 unit per hari, yang berbeda nyata dengan perlakuan penyuntikan supernatan jamur antagonis (Tabel 3).

Laju infeksi berkaitan dengan perkembangan penyakit dan tidak terlepas dari suhu, kelembapan, dan $\mathrm{pH}$ tanah. Kondisi lingkungan saat penelitian memengaruhi keaktifan patogen, kerentanan inang, dan interaksi dalam medium pasir (Agrios, 2005). Laju infeksi penyakit layu fusarium terendah terjadi pada perlakuan dengan supernatan $T$. harzianum isolat jahe $(0,001$ per unit per hari), isolat pisang $(0,00103$ per unit per hari), dan $G$. virens $(0,00105$ per unit per hari) atau terjadi penurunan laju infeksi sebesar $61,48 \%$. Penggunaan F. equiseti tidak berpengaruh nyata terhadap penurunan laju infeksi bila dibandingkan kontrol.

Keefektifan Antagonis. Hasil pengamatan menunjukkan bahwa aplikasi supernatan jamur antagonis menunjukkan keefektifan antagonis sangat baik. Aplikasi supernatan $T$. harzianum, $T$. koningii, F. equiseti, dan G. virens memberikan keefektifan sangat baik bila dibandingkan KO. Hal ini diduga karena jamur antagonis tersebut mampu memengaruhi pembentukan senyawa glikosida, tanin, dan saponin (Tabel 2) pada tanaman, yang dapat menekan pertumbuhan jamur Foc. Diduga dengan adanya penyuntikan supernatan jamur antagonis, terjadi peningkatan produksi metabolit sekunder pada tanaman, seperti glikosida, saponin, dan tannin, melalui pemanfaatan metabolit sekunder (supernatan) jamur antagonis, yang ditranslokasi ke seluruh jaringan tanaman (Naim, 2004).

Populasi akhir. Populasi Fusarium total terendah terdapat pada perlakuan dengan supernatan jamur T. harzianum isolat pisang, yaitu sebesar $5,25 \times 10^{2}$ upk/g tanah atau terjadi penurunan sekitar $45,35 \%$ dibandingkan kontrol (Tabel 9). Hal ini sesuai dengan penggunaan mikroba $T$. harzianum dalam medium pemasteuran yang dapat menurunkan kepadatan sampai 47,12\% (Haryono, 2007). Hasil pengamatan akhir menunjukkan adanya penurunan kepadatan konidium/ ml larutan. Hal ini diduga karena keberadaan F. oxysporum semakin berkurang, yang disebabkan oleh pengaruh suhu yang terlalu ekstrim pada awal penanaman, yaitu sekitar $34^{\circ} \mathrm{C}$, yang memungkinkan konidium Fusarium oxysporum membentuk struktur tahan dan ikut terbawa dalam aliran air (tercuci oleh air). 
Tabel 4. Pengaruh perlakuan terhadap pertumbuhan tanaman

\begin{tabular}{|c|c|c|c|c|c|c|}
\hline Perlakuan & $\begin{array}{l}\text { Bobot basah } \\
\text { akar }(\mathrm{g})^{\mathrm{t}}\end{array}$ & $\begin{array}{c}\text { Selisih tinggi } \\
\text { tanaman }(\mathrm{cm})^{\text {tn }}\end{array}$ & $\begin{array}{c}\text { Jumlah } \\
\text { akar }^{\text {tn }}\end{array}$ & $\begin{array}{l}\text { Jumlah } \\
\text { daun }^{\text {tn }}\end{array}$ & $\begin{array}{c}\text { Panjang akar } \\
\text { terpanjang }(\mathrm{cm})^{\text {tn }}\end{array}$ & $\begin{array}{l}\text { Diameter batang } \\
\text { semu }(\mathrm{cm})^{\text {tn }}\end{array}$ \\
\hline $\mathrm{KO}$ & 6,883 & 44,908 & 13,500 & 5,253 & 15,6425 & 1,1300 \\
\hline FE & 6,278 & 38,000 & 12,838 & 4,753 & 12,5575 & 1,0093 \\
\hline TK & 7,708 & 52,125 & 14,668 & 5,963 & 13,9325 & 1,1350 \\
\hline GV & 7,150 & 51,375 & 14,168 & 5,503 & 15,8400 & 1,1100 \\
\hline THP & 8,397 & 50,910 & 17,755 & 6,170 & 21,2575 & 1,3190 \\
\hline THG & 10,36 & 51,083 & 18,503 & 5,503 & 23,7075 & 1,2225 \\
\hline THJ & 9,413 & 55,235 & 14,835 & 5,420 & 20,2000 & 1,1925 \\
\hline
\end{tabular}

Keterangan: $\mathrm{KO}=$ Tanpa supernatan jamur antagonis, $\mathrm{FE}=$ Supernatan $F$. equseti, $\mathrm{TK}=$ Supernatan $T$. koningii, $\mathrm{GV}=$ Supernatan $G$. virens, $\mathrm{THP}=$ Supernatan $T$. harzianum isolat pisang, $\mathrm{THG}=$ Supernatan T. harzianum isolat gingseng, dan THJ = Supernatan T. harzianum isolat jahe. Angka yang diikuti huruf yang sama pada kolom yang sama tidak berbeda nyata menurut DMRT taraf $5 \%$. $\mathrm{tn}=$ tidak berbeda nyata.

\section{Pengaruh perlakuan terhadap pertumbuhan bibit}

pisang. Berdasarkan hasil pengamatan, diketahui bahwa bobot basah akar, tinggi tanaman, jumlah akar, jumlah daun, panjang akar terpanjang, dan diameter batang semu antara perlakuan dengan kontrol tidak berbeda nyata. Hal ini disebabkan oleh perawatan bibit yang optimum dengan keadaan lingkungan yang sesuai. Akan tetapi, berdasarkan hasil pengamatan menunjukkan adanya potensi dari supernatan jamur antagonis untuk dapat meningkatkan pertumbuhan tanaman. Hal ini dapat dilihat dari bobot basah akar, tinggi tanaman, jumlah akar, jumlah daun, panjang akar terpanjang, dan diameter batang semu, yang menunjukkan adanya peningkatan pada perlakuan supernatan jamur antagonis dibandingkan dengan kontrol (Tabel 4).

Meskipun tidak berbeda nyata secara statistika, tetapi berdasarkan data pada Tabel 4 nampak bahwa perlakuan THP, THG, dan THJ secara umum memberikan kenaikan terhadap komponen pertumbuhan yang diamati. Hal ini diduga bahwa jamur antagonis yang diperlakukan mampu mempunyai mekanisme plant growth promoting fungi (PGPF) yang terbawa supernatan. Seperti yang diungkap oleh Sutanto et al. (2004), bahwa T. harzianum dan T. koningii mampu memacu pertumbuhan tanaman tomat dan tembakau dengan berat kering masing-masing meningkat sekitar 213-275 dan 259-318\%.

\section{SIMPULAN}

1. Ketahanan tanaman bibit pisang Ambon Kuning terhadap penyakit layu fusarium mengalami peningkatan setelah diimbas dengan supernatan jamur T. koningii, T. harzianum, dan G. virens, yang ditunjukkan oleh peningkatan kandungan glikosida, tanin, dan saponin. Supernatan $F$. equiseti belum mampu meningkatkan ketahanan bibit pisang.

2. Supernatan jamur T. koningii, T. harzianum, dan G. virens efektif mengendalikan penyakit layu fusarium pada tanaman pisang Ambon Kuning, yang reratanya ditunjukkan oleh perlambatan masa inkubasi sekitar $48,71 \%$, penurunan keparahan penyakit sekitar 53,57\%, penurunan laju infeksi sebesar $61,48 \%$, peningkatan keefektifan jamur antagonis sebesar $51,26 \%$, dan penurunan kepadatan populasi akhir sebesar 45,35\%.

3. Supernatan jamur T. koningii, T. harzianum, dan G. virens belum mampu memacu pertumbuhan bibit pisang Ambon Kuning.

\section{SANWACANA}

Kelancaran penelitian ini didukung oleh banyak pihak. Penulis mengucapkan terima kasih kepada Dekan Fakultas Pertanian Unsoed atas pendanaannya serta kepada Sdr. Oka Dwi Handaru, Sdri. Nur Azizah, dan Sdr. C. Basir atas bantuan teknisnya selama penelitian berlangsung. 


\section{DAFTAR PUSTAKA}

Adriansyah, A. 2002. Uji metabolit sekunder Trichoderma sp. sebagai antimikrobia patogen tanaman (Fusarium oxysporum) secara in vitro. (On-line)http://digilib.gunadarma.ac.id/ go.php?id=jiptumm-gdl-s1-2002-agung-5821metabolit. Diakses tanggal 14 Januari 2004.

Agrios, G.N. 2005. Plant Pathology, $5^{\text {th }}$ ed. Elsevier Academic Press, California.

Anonim. 2008. Senyawa-senyawa metabolit se kunder. ( O n - l i n e ) h t t p:// darksazuke.blogspot.com/2008_10_01_archive. html. Diakses tanggal 14 Januari 2009.

BPS. 2008. Production of Fruits in Indonesia. (Online) http://www.bps.go.id/sector/agri/horti/ table8.shtml. Diakses tanggal 5 Januari 2009.

Chairul. 2003. Identifikasi Secara Cepat Bahan Bioaktif Pada Tumbuhan di Lapangan. Berita Biologi 6 (4) : 621-628.

Cutler, H.G., S.J. Cutler, S.A. Ross, K. El Sayed, F.M. Dugan, M.G. Bartlett, A.A. Hill, R.A. Hill, \& S.R. Parker. 1999. Koningiin G, a New metabolite from Trichoderma aureoviride. J. Nat. Prod. 62 : 137-139.

Daryanto. 2002. Langkah penanggulangan penyakit layu pisang di Indonesia. Makalah dalam Seminar Nasional Pengendalian Penyakit Layu Pisang. Padang, 22 -23 Oktober 2002.

De Meyer, G., J. Bigirimana, Y. Elad, \& M. Hofte. 1998. Induced systemic resistance in Trichoderma harzianum Y39 biocontrol of Botrytis cinerea. European J. Plant Pathology 104 : 279-286.

Desmawati. 2006. Pemanfaatan Plant Growth Promoting Rhizobacter (PGPR) Prospek yang Menjanjikan Dalam Berusaha Tani Tanaman Hortikultura. POPT Direktorat Perlindungan Tanaman Hortikultura. Ditjen Hortikultura. Nganjuk. (On-line) http://ditlin.hortikultura.go.id/ tulisan/tuli san_desmawati.htm. Diakses tanggal 16 Januari 2009.
Djaya, A.A., R.B. Mulya, Giyanto, \& Marsiah. 2003. Uji Keefektifan Mikroorganisme dan Bahan Organik terhadap Penyakit Layu Fusarium (Fusarium oxysporum) pada Tanaman Tomat. Prosiding Kongres Nasional XVII dan Seminar Ilmiah PFI, Bandung 6-8 Agustus 2003. Hlm.6170.

Eziashi, E.I., N.U. Uma, A.A. Adekunle, \& C.E. Airede. 2006. Effect of metabolites produced by Trichoderma species against Ceratocystis paradoxa in culture medium. African Journal of Biotechnology 5 (9) : 703-706.

Gamliel, A., A. Grinstein, Y. Peretz, I. Klein, A. Nachmiaz, L. Tsror, I. Livescu, \& J. Katan. 1997. Reduced dosage of methyl bromide for controlling Verticillium wilt of potato in experimental and commercial plots. Plant Disease 81 : 469-474.

Hammerschimdt, R. \& E.K. Dann. 2000. Induced Resistance to Disease. Environmentally Safe Approach to Crop Disease Control. Chapter 8. Lewish Publishers, Boca Raton. pp. 177-194.

Haryono, J. 2007. Penekanan hayati penyakit busuk hati pada pisang di pesemaian PT Nusantara Tropical Fruit, Lampung. Skripsi. Fakultas Pertanian, Universitas Jenderal Soedirman, Purwokerto. (Tidak dipublikasikan).

Heil, M. \& R.M. Bostock. 2002. Induced Systemic Resistance (ISR) Against Pathogens in the Context of Induced Plant Defences. Annals of Botany 89: 503-512. (on-line) http// www.aob.oupjournals.org. Diakses tanggal 16 Januari 2009.

Kompas. 16 Februari 2007. Layu Fusarium serang 11.000 Hektar di Kaltim. (On-line). http:// www.kompas.com/ver1/Nusantara/0702/16/ 135927.htm. Diakses tanggal 12 Januari 2008.

Kuswinanti, T. 2006. Efektivitas Trichoderma harzianum dan Gliocladium virens dalam menekan pertumbuhan Sclerotium rolfsii, penyebab penyakit busuk pangkal batang pada tanaman kacang tanah. Buletin Penelitian 9 (1) :10-17. 
Levy, N.O., Y. Elad, N. Korolev, \& J. Katan. 2004. Resistance induced by soil biocontrol application abd soil solarization for the control of foliar pathogens. IOBC wprs Bulletin 27 (1) : 171-176.

Lo, K.H. 2002. Nutrient Solution Recipes. (On-line). http://plant.tc.cfans.umn.edu/listserv/2002/ $\log 0202 / \mathrm{msg} 00278 . h t m l$. Diakses tanggal 12 November 2008.

Mak, C., A.A. Mohamed, K.W. Liew, \& Y.W. Ho. 2008. Banana Improvement. FAO (On-Line).http:// www.fao.org/docrep/007/ae216e0k.htm. Diakses tanggal 15 Agustus 2008.

Mansfield, J.W. 2000. Antimicrobial Compounds and Resistance. Pp. 325-370. In: A.J. Slusarenko, R.S.S. Fraser, \& L.C. van Loon (eds), Mechanisms of Resistance to Plant Disease. Kluwer Academic Publiser. London.

Naim, R. 2004. Senyawa Antimikroba dari Tanaman. Kompas (on-line)http://www2.kompas.com/ kompas cetak/0409/15/sorotan/1265264.htm. Diakses tanggal 14 Januari 2004.

Nasir, N., P.A. Pittaway, K.G. Pegg, \& A.T. Leisle. 1999. A pilot study investigating the complexity of fusarium wilt of bananas in West Sumatra, Indonesia. Aust. J. Agric. Res. 50 :1279-1283.

Nasir, N., Jumjunidang, Riska, \& E. Fredika. 2003. Kultivar pisang komersial yang diserang oleh Fusarium oxysporum f.sp. cubense ras $4 \mathrm{di}$ Sumatra dan Jawa Barat. Makalah dalam Kongres Nasional XVII dan Seminar Ilmiah Perhimpunan Fitopatologi Indonesia, Bandung, 6-8 Agustus 2003.

Pegg, K.G., N.Y. Moore, \& S. Bentley. 1996. Characterisation of a unique population of Fusarium oxysporum f.sp. cubense causing Fusaerium wilt in Cavendish bananas at Carnavorn, Western Australia. Australian Journal of Agricultural Research 46 : 167-178.
Rustati, R., L. Soesanto, \& M. Wachjadi. 2004. Pengendalian Fusarium oxysporum Schlecht. f.sp. zingiberi Trujillo Pada Tanaman Jahe Dengan Disinvestasi Tanah Secara Hayati. Hlm. 259-267. Dalam: L. Soesanto (Ed.), Prosiding Symposium Nasional I Tentang Fusarium, Purwokerto, 26-27 Aguatus 2004.

Santoso, S.E., L. Soesanto, \& T.A.D. Haryanto. 2007. Penekanan hayati penyakit moler pada bawang merah dengan Trichoderma harzianum, Trichoderma koningii, dan Pseudomonas fluorescens P60. Jurnal HPT Tropika 7 (1) : 53-61.

Semangun, H. 2000. Penyakit-penyakit Tanaman Hortikultura di Indonesia. Gadjah Mada University Press. Yogyakarta.

Soesanto, L., Soedharmono, N. Prihatiningsih, A. Manan, E. Iriani, \& J. Pramono. 2005. Potensi agensia hayati dan nabati dalam mengendalikan penyakit busuk rimpang jahe. Jurnal HPT Tropika 5 (1) : 50-57.

Soesanto, L., Rokhlani, \& N. Prihatiningsih. 2008. Penekanan beberapa mikroorganisme antagonis terhadap penyakit layu fusarium gladiol. Agrivita 30 (1) :75-83.

Suganda, T. 2000. Penginduksian resistensi sistemik buah cabai merah terhadap penyakit antraknos dengan pengaplikasian penginduksi biotik dan abiotik. Jurnal Agrikultura 11 (2) : 67-75.

Sutanto, A., R.Y. Purba, \& Sudharto. 2004. Pengendalian hayati Penyakit Fusarium pada tanaman Hortikulturs di Brastagi Sumatra. Hal. 229-237. Dalam: L. Soesanto (Ed.), Prosiding Symposium Nasional I Tentang Fusarium, Purwokerto, 26-27 Agustus 2004.

Suyadi. 2004. Perkembangan dan Penyebaran Serangan Fusarium Pada Pertanaman Pisang di Kalimantan Timur. Hal. 182-192. Dalam: L. Soesanto (Ed.), Prosiding Symposium Nasional I tentang Fusarium, Purwokerto, 26-27 Agustus 2004. 
Syatrawati. 2005. Pengaruh kultur filtrat Gliocladium virens terhadap Rhizoctonia solani untuk mengendalikan penyakit dumping-off pada jagung. Jurnal Sains dan Teknologi 5 (3): 142146.

Untung. K. 1996. Pengantar Pengelolaan Hama Terpadu. Gadjah Mada University Press, Yogyakarta.

Vallad, G.E. \& R.M. Goodman. 2004. Systemic Acquired Resistance and Induced Systemic Resistance in Conventional Agriculture. Crop Science Society of America 44 : 1920-1934. van der Plank, J.E. 1963. Plant Diseases: Epidemics and Control. Academic Press, New York.

Wirianata, H. 2004. Mekanisme Ketahanan Kakao terhadap Penyakit Busuk Buah (Phytophthora palmivora). Disertasi. Universitas Gadjah Mada, Yogyakarta (tidak dipublikasikan). 